\title{
Management Efficiency of Budgeting: Evidence from Public Universities in Vietnam
}

\author{
Oanh Thi Tu LE $P h D$ \\ Accounting Department \\ University of Labour and Social Affairs, Vietnam \\ E-mail: oanhletu@gmail.com \\ Nga Thi Nguyen $P h D$ \\ Accounting Department \\ University of Labour and Social Affairs, Vietnam \\ E-mail: nguyennga270781@gmail.com
}

\begin{abstract}
Budgeting is an important tool helping managers in planning and controlling during the operation of universities. Budgeting plays a vital role in controlling budgeting activities in the short-term and provides appropriate implementation plans to achieve strategic objectives. This study aims to evaluate the management effectiveness of budgeting activities in Vietnamese public universities. Data was collected from 53 public universities in Vietnam through questionnaire. After collecting, the data is cleansed and analyzed on SPSS software by tools such as: Frequency statistics, price statistics, average, comparing. The research results showed that: (I) The application of budgeting is comprehensive; that includes income and expenditure budget, enrollment budget, and teaching budget; (2) Monitoring and evaluation of budgeting activities are strictly implemented, (3) The main budgeting method is preparing general budgets for the entire university, and the other method is preparing budgets for each department (4) The main method of evaluating budgeting is comparing variances while variance analysis and finding underlying causes were not applied. This study proposes solutions to improve the process, content and quality of budgeting, thereby contributing to improving management efficiency in public universities in Vietnam.
\end{abstract}

Keywords: Monetary Policy, Cash Reserve Ratio, Profitability.

JEL Classification: MIO, M40, M4I.

\section{Introduction}

Planning and implementation of plans play an important role in the success of any organization. A budget is an estimation of revenue, expenses or production over a specified future period of time (Little, Magner, \& Welker, 2002). This means budgeting is critical for any organization. Budgeting helps managers foresee the financial fluctuations of their departments, thereby providing solutions to overcome problems and promote strengths. Furthermore, Suberu (2010) supposed that budgeting helps managers in monitoring, controlling and evaluating business activities. It facilitates the efficient use of resources, improves decision making, and provides benchmarking to evaluate organizational performance. Effective budgeting activities require identifying organizational targets, assigning tasks and responsibilities to achieve the objectives (Drake \& Fabozzi, 20I0). Kavoi (20II) provided that budgeting reflects the organizational directions in the future and is essential for planning. Gachithi (20I0) asserted that budgeting is a powerful planning tool for the future. In addition, Suberu (2010) stated that effective and reliable budgeting facilitates efficient use of available resources, improves decision making, and provides a benchmark for evaluating and controlling management efficiency.

In Vietnam, public universities use funds, assets and facilities allocated by the government to fulfill the teaching goals. Public universities are autonomous in their operations and are under competition pressure to attract students. Since public universities are given more autonomy in operations, they have to operate more efficiently and effectively. Budgets in universities are used to support strategic planning for the future. Budgeting in universities require the allocation of resources to activities or specific programs. Therefore, universities are seeking better ways to allocate funds and control expenses. Effective budgeting requires support from management, effective collaboration between managers and staff, and well-organized reporting systems (Lucey, 2002). The question is whether the current budgeting activities in public universities in Vietnam actually help managers 
to control and improve management efficiency. Also, literature review shows that the issue of budgeting in Vietnamese public universities has not received much attention. Therefore, this study investigated management efficiency of budgeting in public universities in Vietnam. Then, potential solutions are proposed to improve management efficiency of budgeting in Vietnamese public universities.

\section{Literature Review}

Budgeting is the allocation of financial resources needed to carry out the business plans. Budgeting is not merely about planning costs and profits, but also refers to the allocation of resources to departments and divisions to achieve the operational goals and strategies of enterprises. Therefore, budgeting is a useful management tool describing an overall picture of operational and strategic goals, serving the short-term and long-term plans.

Hansen and Maryanne (2000) suggest that budgeting which is prepared by managers of an organization is measured by specific standards in certain period of time. Frederick (200I) defined budgeting as a timely plan which can be measured in terms of money. An effective budget allows the evaluation of financial capacity for a specific strategic plan. Lucey (2002) provided that a budget is the quantitative report including revenues, assets, liabilities and cash flows over a specified period of time. In most organizations, the annual plan is formalized by budgeting and effective monitoring of the budgets (Silva $\&$ Jayamaha, 2012).

To achieve certain goals, organizations develop short-term or long-term strategies. Usually strategic plans of many organizations cover a period of three to five years. A strategic plan should include a financial plan or budgeting to achieve its goals. The strategic plan is made from the annual plan and therefore the annual budget. The annual plans provide detailed activities which need to be implemented during the year. According to Schick (I999), budgeting helps organization plan and allocate limited resources efficiently to achieve certain goals. A budget is a plan which is prepared by managers includes organizational targets and detailed actions in long-term (Hansen \& Maryanne, 2000). Annual budgets are usually divided by month or quarter. Annual budgets are adjusted and updated every year (Muleri, 200I).

According to Anthony and Govindarajan (200I), budgeting has a positive impact on management efficiency. Fisher, Maines, Peffer, and Sprinkle (2002) proved that allocation of resources improves performance of staff. Budgeting is a management tool for controlling, promoting and evaluating performance. In order to achieve specific targets or visions, an organization need to ensure that all departments work towards the same goals (Zimmerman, 2003). The reason is that all departments relate to each other in many ways; therefore, managers of departments need to take responsibilities for their departments and know how to communicate and cooperate with other departments effectively. Otherwise, resource allocations would be inefficient (Weetman, 2006). Furthermore, efficiency tends to increase when managers use budgets to allocate resources (Tavakkoli \& Etemadi, 2007). According to John and Ngoasong (2008), budgeting facilitates the creation and maintenance of competitive advantages in the following management functions: (I) forecasting and planning, (2) communication and coordination, (3) motivation, (4) evaluating and controlling, and (5) decision making.

Wong-On-Wing, Guo, and Lui (2010) supposed that management efficiency is the result of the work of each member in management activities such as planning, investigating, coordinating, controlling, negotiating and representation. Management efficiency shows managers' ability to conduct management functions within the scope of their responsibility. Budgeting is one of the management tools to evaluate management efficiency. Many researchers emphasized that the effective budgeting helps to improve the overall organizational efficiency.

Muleri (200I) assumed that budgeting includes all steps of preparing budgets, approving and implementing tasks. Budgeting can be an effective, wide-ranging discussion between the headquarters and implementation units. Particularly, any issue can be discussed such as conditions, as well as obstacles in the actual environments. The budgeting process involves estimating an organization's incomes and expenditures, implementing plans, monitoring and reporting performance. Therefore, a budget is simply the financial plan of any organization. Blumentritt (2006) suggest that budgeting applied correctly, budgets can improve the ability to organize and maintain high performance. Budgeting and strategic management which are put into practice properly can have positive impact on company performance. Suberu (2010) provided that a good budgeting process which combines specific visions with organizational goals can improve performance, decision making, and connection with stakeholders.

This study investigated budgeting and its impact on management efficiency in companies, public educational institutions and other organizations.

Ambetsa (2004) on budget control practices of commercial airlines operating at airports indicated that airlines use budgets to make plans and evaluate their business performance. The results showed that all firms had systematic and formal budgeting process, while others had informal budgeting activities with some forms and practices of budget control.

Qi (2010) conducted a study to evaluate how budgeting affects the performance of small and medium-sized enterprises in China. The study used quantitative research method and concluded that the formal budgeting process positively affects the efficiency of small and medium-sized enterprises in China. 
Almasi, Palizdar, and Parsian (2015) conducted a study on the impact of managers' participation in preparing budgets on management efficiency in electricity companies in Tehran. The results showed a significant relationship between variables related to managers and management efficiency.

John and Ngoasong (2008) investigated the impact of budgeting process on budget efficiency in public organizations in Kenya. By correlation and regression analysis, the study proved that there is a strong relationship between budgeting and budget efficiency.

In public sector, Muleri (200I) examined budgeting processes in non-governmental organizations in Kenya. The study provided that there were limitations in the budgeting process that led to cost reductions to achieve cost effectiveness. Furthermore, there was a lack of bases for implementing budget control. It argued that although profit is a key indicator of efficiency in public sector, budget management should be measured based on strong financial policy. The study concluded that budgeting is widely accepted in assessment and is used to convey action plans. Muleri (200I) conducted a study on budgeting practices in major British non-governmental organizations in Kenya. The study focused on budgeting practices and the level of budgeting used as a management control tool. The results showed that $100 \%$ of projects used income budgets.

Alau (2009) conducted a study on efficiency of budgeting process in the public sector in Nigeria. The study showed that the current budgeting process is significantly effective regarding the use of budgets. The study suggested to improve budgeting process and budget control based on the existing legal framework of relevant laws.

Gacheru (2012) conducted to determine the relationship between the budgeting processes and budget variances in non-governmental organizations in Kenya. The study used questionnaires to collect data and analyzed data using SPSS I7. The study found that changing one unit in budgeting would result in a $0.722 \%$ change in the budget; changing one unit in budget control would result in $0.661 \%$ change in the budget, changing one unit in budget implementation would result in a $0.682 \%$ change in the budget. The study concluded that budget preparation, budget implementation and budget control significantly influence budget variances.

Cropper and Cook (2000) pointed out that many universities are not satisfied with their cost accounting system and are seeking ways to change them. With limited financial resources, it is necessary for universities to offset the costs with the revenue from training courses to better manage resources. Horne and $\mathrm{Hu}$ (2008) conducted a study on efficiency of using teaching resources of Australian universities use their teaching resources. The study estimated the cost effectiveness of 36 universities in the period 1995-2002. The results showed that universities did not operate efficiently. Muthinji (2009) conducted a study on challenges of budget implementation and its efficiency in universities. The study found that budgeting plays a vital role in management and managers at all levels are increasing the use of budgeting.

Sugioko (2010) examined the impact of managers' participation in budgeting on management efficiency of member universities of APTIK in Indonesia. Data were collected by sending questionnaires via email to 850 executive directors of I6 APTIK's member universities with a response rate of $46.94 \%$. The results showed that participation of managers in budgeting has a positive and significant impact on the performance of executive directors of universities.

Gachithi (2010) conducted a study in Nairobi University. Questionnaires were sent to 8 administrators, 6 managers, 8 senior members of the Budget Committee, II financial officers and managers participating in budget preparation. The results showed that Nairobi University did not have an effective budget preparation process. It could be explained by insufficient allocation of funds to the department, institutional weaknesses that hinder effective budget implementation, and inadequate methods of allocating funds to departments. The study suggested Nairobi University to mitigate challenges of budgeting, provide effective guidelines for capital allocation and implementation policies. Another study conducted in Nairobi University from Kavoi (20II) found that sufficient planning and accurate estimates in budget preparation have impacts on performance targets of this university.

\section{Research Methodology}

The study was conducted through sending questionnaires to the accounting department of I38 Vietnamese public universities. The questionnaire was divided into 5 main parts: (i) the current situation of budgeting; (ii) the current situation of budgeting assessment; (iii) suggestions regarding the assignment of budgeting; and (v) Information of respondents and public universities. The identification the current situation of budgeting used Yes/No questions. The assessments on budgeting were measured using the 5-point Likert scale, in which I-"Strongly disagree" to 5-"Strongly agree". The number of valid answers was 55 from 53 public universities. With the response rate was $40 \%$, the minimum sample size is $4 \mathrm{I}$ according to Nguyen and Nguyen (2015). Therefore, the sample is appropriate for further analysis. 
Table I. Demographic Characteristics

\begin{tabular}{llll}
\hline Respondents & & No $=55$ & $\%$ \\
\hline Gender & Female & $4 \mathrm{I}$ & 74.5 \\
\cline { 2 - 4 } & Male & $\mathrm{I}$ & 25.5 \\
\hline \multirow{2}{*}{ Job position } & Chef accountant & 7 & $\mathrm{I}$ \\
\cline { 2 - 4 } & Accountant & 48 & 87.3 \\
\hline Experiences & $<5$ years & 8 & $\mathrm{I}$ \\
\cline { 2 - 4 } & 5-I0 years & 20 & 36.5 \\
\cline { 2 - 4 } & $>$ I0 years & 27 & 49.1 \\
\hline Education level & Post graduate & 42 & 76.4 \\
\cline { 2 - 4 } & Bachelor & $\mathrm{I3}$ & $\mathbf{2 3}$ \\
\hline Total & & $\mathbf{5 5}$ & $\mathrm{I00} \%$ \\
\hline
\end{tabular}

Regarding characteristics of respondents (Table I), out of 55 people participating in the survey, most respondents were female $(4 \mathrm{I} ; 74.5 \%)$ and accountants $(48 ; 87.3 \%)$. Regarding working tenure, the majority of respondents had been working for more than 10 years $(27 ; 49.1 \%)$, which is followed by the number of respondents who had been working from 5 to I0 years $(20 ; 36.4 \%)$. Regarding the educational level, the number of postgraduates was higher than the number of university graduates $(42 ; 76.4 \%)$. Demographic results showed that respondents are appropriate to collect relevant data on the management accounting application of public universities for the following reasons: (i) accounting is often attracted more women than men; (ii) accountants in public universities are officials, who prefer stability to flexibility compared to other jobs so they are loyal with universities; (iii) the university environment always encourages accountants to improve their education, affect development opportunities and income, therefore, higher education level is required.

Table 2. Universities Characteristics

\begin{tabular}{llll}
\hline University & & No $=53$ & $\%$ \\
\hline Autonomy Degree & Non autonomy & 8 & $\mathrm{I} 5 . \mathrm{I} \%$ \\
\cline { 2 - 4 } & Semi autonomy & 29 & $54.7 \%$ \\
\cline { 2 - 4 } & Full autonomy & $\mathrm{I} 6$ & $30.2 \%$ \\
\hline Years of establishment & $<$ I0 years & 3 & $5.7 \%$ \\
\cline { 2 - 4 } & I0 - 20 years & 9 & $\mathrm{I7.0} \%$ \\
\cline { 2 - 4 } & $20-50$ years & $\mathrm{I}$ & $30.2 \%$ \\
\cline { 2 - 4 } & $>50$ years & 25 & $47.2 \%$ \\
\hline Location & Northern & 30 & $56.6 \%$ \\
\cline { 2 - 4 } & Central & $\mathrm{II}$ & $20.8 \%$ \\
\cline { 2 - 4 } & Southern & $\mathrm{I}$ & $\mathbf{2 2} .6 \%$ \\
\hline Total & & $\mathbf{5 3}$ & \\
\hline
\end{tabular}

Source: Compiled from the survey

Regarding the characteristics of public universities participating in this study (Table 2), out of 53 surveyed universities, 16 were fully autonomous, 29 were partially autonomous schools and 8 universities were non-autonomous. Regarding the length of operation, the most common group was universities which had been established for 50 years or more $(25 ; 47.2 \%)$. The next most common group was universities which had been established for between 20 and 50 years (I6; $30.2 \%)$. The rest were universities which had been established for less than 20 years. Regarding geographic area, the majority of universities were located in the North of Vietnam (30;56.6\%). The number of universities located in the Central and the South of Vietnam were relatively similar $(20.8 \%$ and $22.6 \%$ respectively). The distribution of 53 public universities was appropriate ( $\mathrm{Vu}, 2017)$.

Data was processed through SPSS 20 software by cleaning and analysis tool. Analysis methods used in this study included descriptive statistics, comparison by statistical methods such as pie charts, bar charts, frequency tables and graphical representations to achieve the research objectives. 


\section{Research Results}

The content of budgeting, current situation of budgeting activities, budget control and evaluation of public universities are shown in Table 3.

Table 3. The content of budgeting

\begin{tabular}{llll}
\hline Content of budgeting & No $=55$ & & Total \\
\cline { 2 - 4 } & Yes & No & 55 \\
\hline I. Revenue budget & 55 & 0 & 55 \\
\hline 2. Expenditure budget & 55 & 0 & 55 \\
\hline 3. Enrollment budget & 55 & 0 & 55 \\
\hline 4. Teaching budget & 34 & 21 & 55 \\
\hline 5. Budget control & 55 & 0 & 55 \\
\hline 6. Budget evaluation & 55 & 0 & \\
\hline
\end{tabular}

Source: Compiled from the survey

Table 3 shows that according to the assessment of accountants, budgeting had been fully conducted by universities, and that includes revenue budget, expenditure budget, and enrollment budget. However, only 34 universities prepared teaching budget (6I.8\%). In addition, budget control and evaluation were also fully implemented by all universities.

Regarding budget period, universities often prepare budgets monthly, quarterly, or annually. Results of budget period of universities are shown in Table 4.

Table 4. Budget period

\begin{tabular}{llll}
\hline Budget period & No $=55$ & & \\
\cline { 2 - 4 } & Yes & No & Total \\
\hline I. Monthly & 2 & 53 & 55 \\
\hline 2. Quarterly & 12 & 43 & 55 \\
\hline 3. Yearly & 53 & 2 & 55 \\
\hline
\end{tabular}

Source: Compiled from the survey

According to the survey results, most universities prepared budgets annually $(53 ; 96.4 \%)$. Some universities prepared quarterly budgets $(12 ; 21.8 \%)$ and only a few prepared monthly budgets $(2 ; 3.6 \%)$.

The methods of preparing budgets are evaluated according to 3 aspects: (i) Each department prepares its own budgets; (ii) The accounting department prepares overall budgets for the entire university; (iii) The accounting department prepares overall budgets for the entire university based on budget of each department and faculty. Details are shown in table 5.

Table 5. The methods of preparing budgets

\begin{tabular}{lll}
\hline Preparing budgets & Frequency & Percentage (\%) \\
\hline I. Budgets prepared by each department & 15 & $27.3 \%$ \\
\hline 2. Overall budgets prepared by the accounting department & 23 & $41.8 \%$ \\
\hline 3. Summary of overall budgets from departments & 17 & $30.9 \%$ \\
\hline Total & 55 & $\mathrm{I00}$ \\
\hline
\end{tabular}

Source: Compiled from the survey

Table 5 shows that $41.8 \%$ of universities had the overall budgets prepared by the accounting department. That was followed by $30.9 \%$ of universities who transferred budget data from departments to the accounting department to make overall budgets for the entire university. Furthermore, only $27.3 \%$ of universities had their budgets prepared by each department.

The study used 5-point Likert scale to assess budget evaluation methods. Results Table 6 shows that universities mainly compared the differences between actual results and estimates, with mean value of $4 . \mathrm{I} 3$ which corresponds to a score of "agree". The second most common method was finding the causes of budget variances (mean value $=3.8$ ). 
The method of differential analysis by department was applied less than other methods (mean value $=3.45$ ). Particularly, the differential analysis of differences by each component (price and quantity) did not receive much attention, with a mean value of 3.4 which corresponds to a score of "agree".

Table 6. Budget evaluation methods

\begin{tabular}{|c|c|c|c|c|c|c|c|c|}
\hline \multirow[t]{2}{*}{ Budget evaluation } & \multirow[t]{2}{*}{$\mathrm{N}$} & \multirow[t]{2}{*}{ Mean } & \multicolumn{6}{|c|}{ Percentage (\%) } \\
\hline & & & SI & $\mathrm{S} 2$ & S3 & $\mathrm{S} 4$ & S5 & S4\&S5 \\
\hline I. Overall estimates and actual comparing & 55 & 4.13 & $0.0 \%$ & $1.8 \%$ & $12.7 \%$ & $56.4 \%$ & $29.1 \%$ & $85.5 \%$ \\
\hline 2. Departments estimates and actual comparing & 55 & 3.45 & $1.8 \%$ & $20.0 \%$ & $23.6 \%$ & $40.0 \%$ & $\mathrm{I} 4.5 \%$ & $54.5 \%$ \\
\hline 3. Variances analysis (cost, volume) & 55 & 3.4 & $\mathrm{I} .8 \%$ & $10.9 \%$ & $34.5 \%$ & $50.9 \%$ & $1.8 \%$ & $52.7 \%$ \\
\hline 4. Causes of budget variances & 55 & 3.8 & $\mathrm{I} .8 \%$ & $5.5 \%$ & $21.8 \%$ & $52.7 \%$ & $18.2 \%$ & $70.9 \%$ \\
\hline
\end{tabular}

Notes: SI (Strong Disagree) and S5 (Strong Agree)

Source: Compiled from the survey)

Regarding frequency of budget evaluation methods in figure I, the method of comparing the differences between overall estimates and actual results received the highest agreement with $85.5 \%$ of respondents answered "agree" or "strongly agree". Finding causes of budget variances received the second highest amount of agreement with $70.9 \%$ of respondents answered "agree" or "strongly agree". The other two methods differential analysis by department and differential analysis by component had similar mean values of 3.45 and 3.4 respectively. The amount of agreement on differential analysis by department $(54.5 \%)$ was higher than that on differential analysis by component.

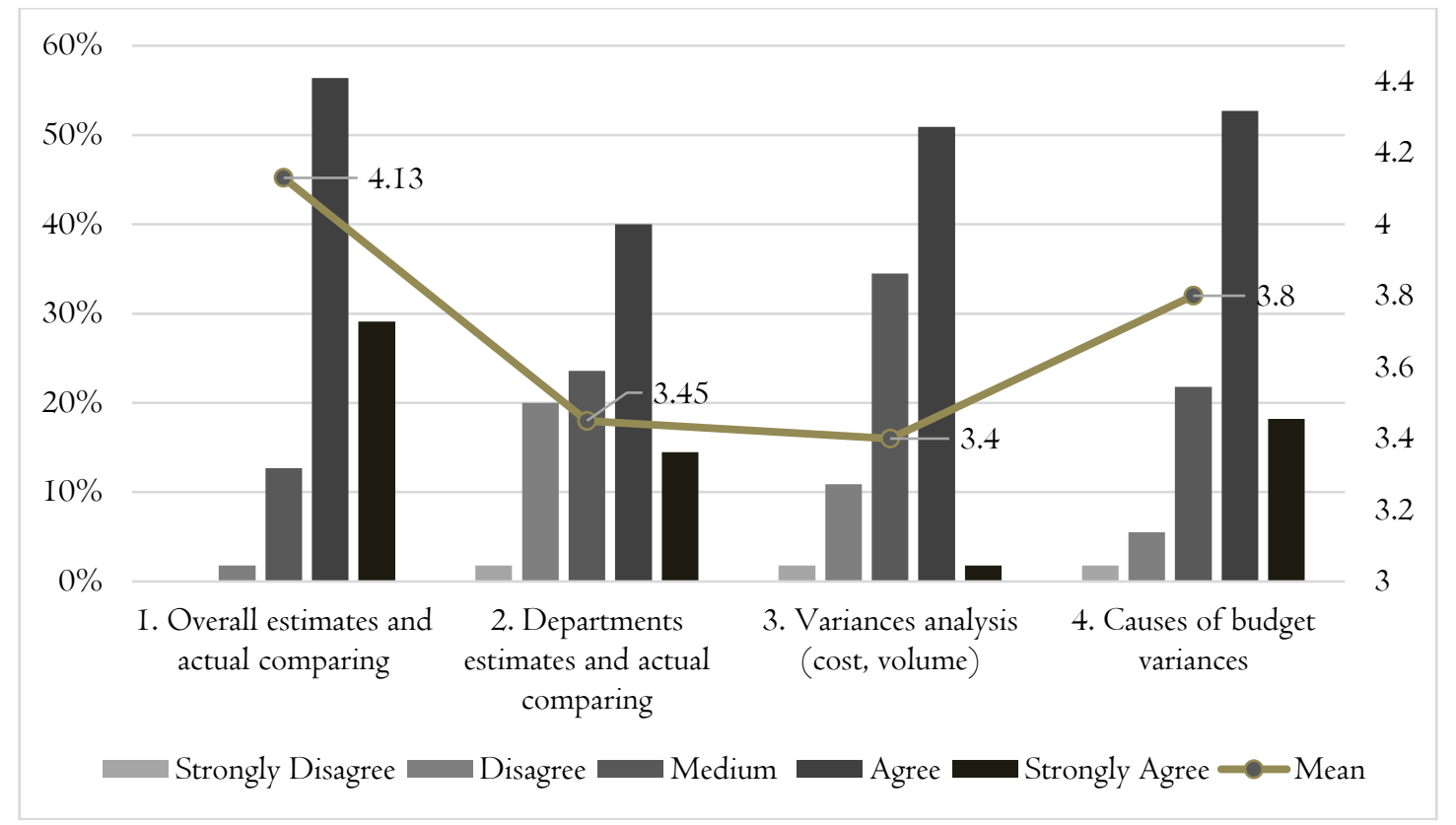

Figure I. Budget evaluation methods by frequency and mean

Thus, the survey indicated that universities conducted budgeting fully, and that includes revenue and expenditure budget, enrollment budget, and teaching budget. In addition, budget evaluation methods received attention from universities. However, budget preparation process is constrained by standards, policies and requirements specified by the government. Therefore, teaching budget was not prepared by many universities (6I.8\%). Furthermore, budgets were often prepared annually by the accounting department for the entire university (41.8\%). The main method of budget evaluation was comparing data. However, universities did not conduct further analysis about the differences of price and quantity and finding causes of differences to make adjustments for the following budget period. Required actions to improve the budgeting process is shown in Table 7 and Figure 2. 
Table 7. Required actions to improve the budgeting process

\begin{tabular}{|c|c|c|c|c|c|c|c|c|}
\hline \multirow[t]{2}{*}{ Budgeting } & \multirow[t]{2}{*}{$\mathrm{N}$} & \multirow[t]{2}{*}{ Mean } & \multicolumn{6}{|c|}{ Percentage (\%) } \\
\hline & & & SI & $\mathrm{S} 2$ & S3 & $\mathrm{S} 4$ & S5 & $\begin{array}{ll}\text { S4 } & \& \\
\text { S5 } & \end{array}$ \\
\hline I. Refining budgeting procedures & 55 & 4.25 & $0.0 \%$ & $0.0 \%$ & $3.6 \%$ & $67.3 \%$ & $29.1 \%$ & $96.4 \%$ \\
\hline 2. Assigning separate estimates to each department & 55 & 3.98 & $0.0 \%$ & $10.9 \%$ & $12.7 \%$ & $43.6 \%$ & $32.7 \%$ & $76.3 \%$ \\
\hline $\begin{array}{l}\text { 3.Establishing enrollment budget based on training } \\
\text { results }\end{array}$ & 55 & 4.15 & $0.0 \%$ & $1.8 \%$ & $12.7 \%$ & $54.5 \%$ & $30.9 \%$ & $85.4 \%$ \\
\hline $\begin{array}{l}\text { 4. Setting up a department for supervising budget } \\
\text { implementation }\end{array}$ & 55 & 4.09 & $0.0 \%$ & $3.6 \%$ & $\mathrm{I} 2.7 \%$ & $54.5 \%$ & $29.1 \%$ & $83.6 \%$ \\
\hline $\begin{array}{l}\text { 5. Budget evaluation based on budget variances } \\
\text { (cost, volume) }\end{array}$ & 55 & 3.78 & $0.0 \%$ & $3.6 \%$ & $30.9 \%$ & $49.1 \%$ & $16.4 \%$ & $65.5 \%$ \\
\hline
\end{tabular}

Table 7 shows that all required actions are necessary for universities with mean values ranging from 3.78 to 4.25 , which correspond to scores of "agree" and "strongly agree" respectively. "Refining budgeting procedures" had the highest mean value, which was followed by "Establishing enrollment budget based on training results" (mean = 4.I5) and "Setting up a department responsible for supervising budget implementation" (mean $=4.09$ ). "Budget evaluation based on budget variances (cost, volume)" had the lowest mean value of 3.78 which correspond to a score of "agree".

Regarding frequency (figure 2), the agreement levels of required actions were relatively high ranging from $65.5 \%$ to 96.4\%. "Refining budgeting procedures" received the highest agreement (96.4\%). "Establishing enrollment budget based on training results" and "Creating a department responsible for supervising budget implementation" had similar amount of agreement $(85.4 \%$ and $83.6 \%)$. "Budget evaluation based on budget variances of cost and volume" had the lowest amount of agreement $(65.5 \%)$.

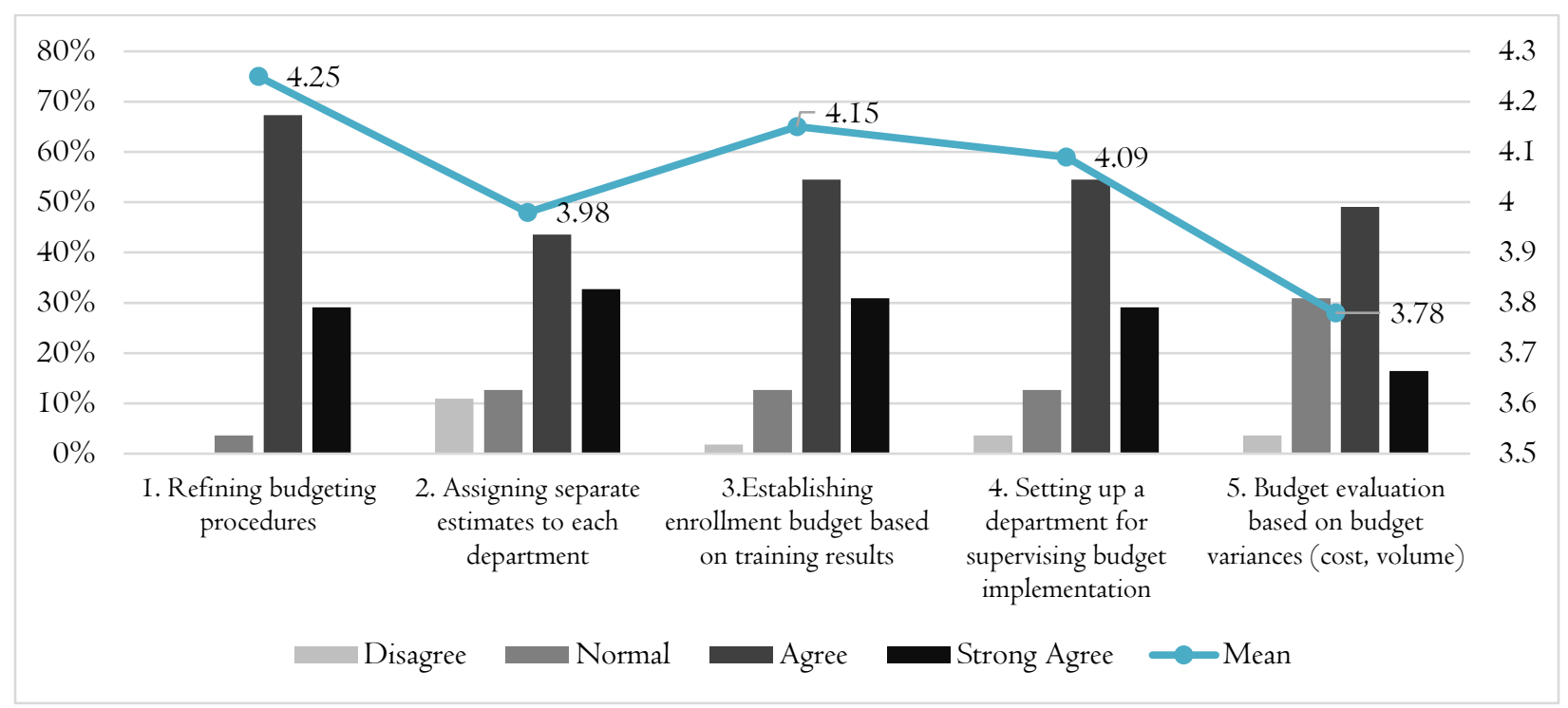

Figure 2. Required actions to improve the budgeting process by frequency and mean

\section{Conclusion and Recommendations}

\section{I Conclusion}

Budgeting of public universities in Vietnam was relatively well implemented regarding revenue and expenditure budget, enrollment budget, budget supervision and evaluation. The establishment of certain cost standards as a basis for budgeting was widely applied. Some universities prepared teaching budget (accounting for 61.8\%). Furthermore, most universities prepared budget annually and had budgets prepared by the accounting department for the entire university. Budget supervision and 
evaluation are also monitored. Annual evaluation based on the comparison between actual results and estimates was conducted (mean value of 4.I3). However, the budgeting process of public universities has following problems:

- Regarding budgeting, although universities conduct fully budgeting process, there exist certain issues. A specific characteristic of public universities is that the government provides and approves funds for their operation activities. Therefore, the budget preparation process is constrained by standards, policies and requirements specified by the government. Therefore, teaching budget was not prepared by many universities (61.8\%). Furthermore, budgets were often prepared annually by the accounting department for the entire university (41.8\%). In addition, universities had their budgets prepared by the accounting departments for the entire universities rather than by each department (only $27.3 \%$ of universities had budgets prepared by departments). There is a lack of sharing budget information between faculties, subjects, departments and units for the purpose of effective budgeting. The analysis of differences in price and quantity as well as investigation of the causes of differences had not been performed systematically to make necessary adjustments for the following budget period.

- Regarding the budget control and evaluation, these works were not conducted frequently. The main method of budget evaluation was comparing data. However, universities did not conduct further analysis about the differences of prices and quantity and finding causes of differences to make adjustments for the following budget period. Therefore, the budget control, evaluation is not conducted promptly to take necessary steps or adjustments in accordance with specific situations. Universities evaluated their performance based on budget variances, but failed to analyze and investigate the impact of such variances on budget implementation. Regarding differential analysis based on component and finding causes of differences, non-autonomous universities had the lowest mean value, which indicates a lack of attention to these issues compared to other groups. Thus, there are certain limitations in providing budget information for managers to make decisions. Currently, due to certain limitations of the budgeting process, universities should refine budgeting procedures, assign departments to prepare separate budgets, and improve budgeting content, budget evaluation.

\subsection{Recommendation}

\subsection{Refining Budget Procedures}

Based on specific characteristics, public universities establish procedures and assign responsibilities for each department regarding tasks and time. Suggestion is shown in figure 3.

Step I. Departments, faculties, units prepare revenue and expenditure budgets based on specific characteristics, policies of certain university and send to the accounting department.

Step 2. The accounting department need to consider budgets submitted by departments based on specific characteristics, policies of certain university to decide whether to approve or not. If any budget is not appropriate, it would be return to its department to amend. If all budgets are approved, the accounting department would prepare the overall budget for the entire university.

Step 3. The accounting department prepares an overall budget for the entire university and sends department budgets and the overall budget to the board of administrators and wait for approval.

Step 4. The board of administrators considers the appropriateness of budgets. If a budget is not appropriate, it would be return to its department. If a budget is appropriate, it would be approved.

Step 5. The accounting department receives the approved budgets, store and keep track on the budgets, and give them back to departments. 
Step 6. Departments, faculties receive the budget decisions, store and keep track on their budgets.

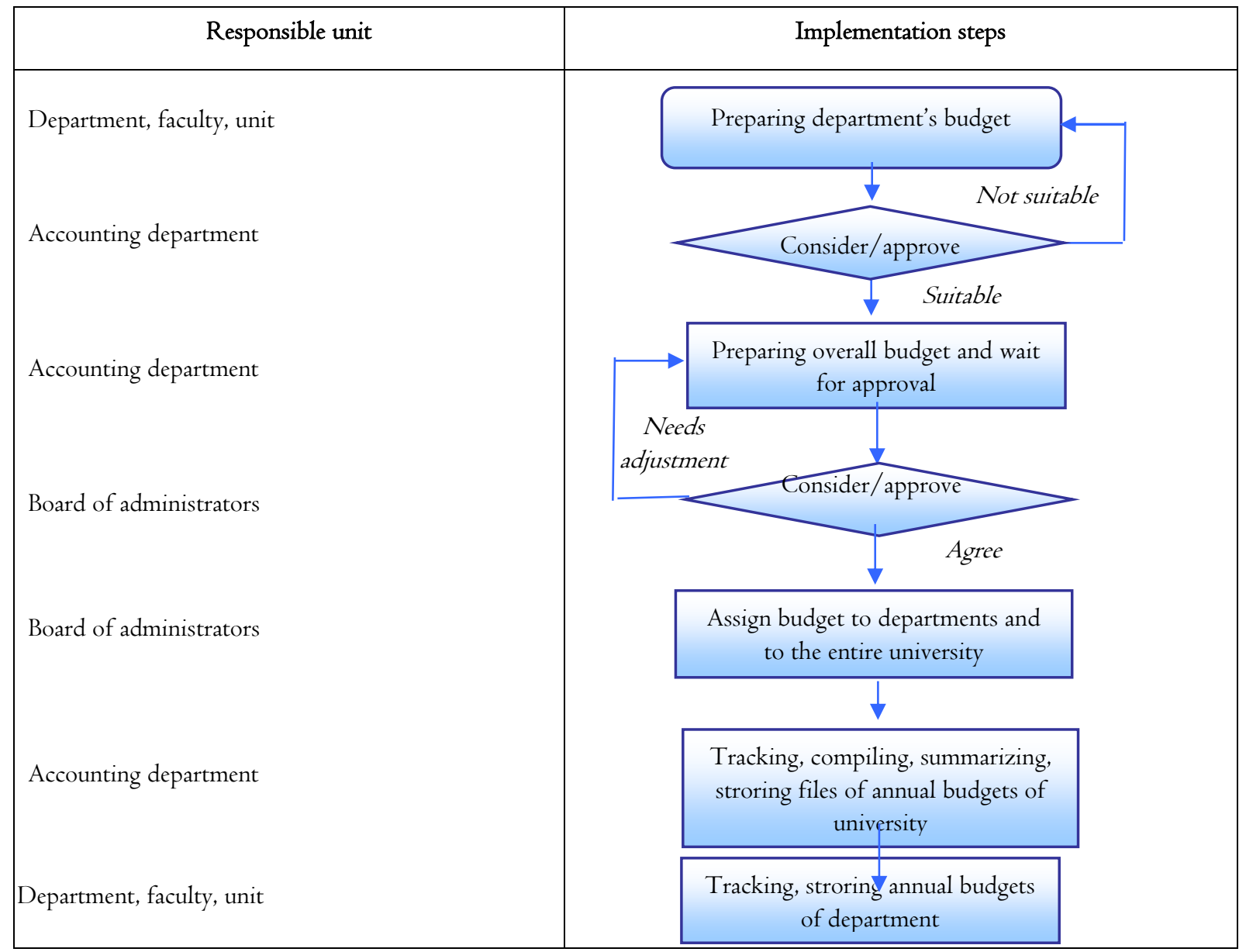

Figure 3. Budget procedures

Source: Compiled by authors

\subsubsection{Refine the Budgets According to Requirements of Management Accounting}

In terms of revenue budgets, universities' revenues come from the state budget, tuition, and there are other sources such as providing services. Budgets have a significant role in universities' management since universities can implement and monitor activities according to the budgets and evaluate the management quality in specific periods. Budgeting is the basis for developing and evaluating management responsibility of the board of administrators; thereby, using resources more effectively to ensure achievement of universities' goals.

Revenue budgets should be prepared based on the estimated number of students and the specified tuition. Other sources of revenue should be estimated based on the capacity and possible opportunities during the financial year. Specifically: (I) Tuition budgets require the department of studies to provide and update the number of current students, the estimated number of enrollment, and the number of graduates so that the accounting department can prepare budgets accurately; (2) For teaching contracts with outsiders: the department of studies needs to update information about the values of current and potential contracts, time, and any changes of the contracts so that the accounting department can prepare budgets accurately; (3) For revenue from dormitories: based on the estimated number of students, specified rent, the dorms' capacity and estimated number of students staying in the dorms to prepare budgets for this source of revenue.

Regarding cost budgets, departments must prepare cost budgets for their units based on the assignment of tasks and submit the budgets to the board of administrators for consideration and approval. Effective budgeting requires cooperation among departments to make accurate estimations. Furthermore, budgeting should be based on standard costs and estimated costs. 
Based on the government's regulations on standard costs for tertiary education and departments, such standard costs can be classified as follows: (I) General costs include: costs of electricity, depreciation, costs of using other services; (2) Administrative costs include: stationary costs, payroll expenses; (3) Teaching costs: These standard costs are the payroll expenses of certain teaching hours to get the minimum wage, the expenses of working overtime, standard costs in cases of working in more than one position.

Based on the standard costs, historical data, and operational targets for each period, budgets are prepared for future period and adjusted based on the specified goals.

To evaluate efficiency of each class, universities should set up standard fixed direct costs of classes, including direct expenses for advertising, other expenses include: electricity costs, administrative costs. In particular, advertising costs are one-time costs to promote the classes to students. It is estimated based on previous data and the range of audience reached. Administrative costs are specified in expenditure regulations of the universities. Other costs which include electricity costs, costs of providing drinking waters to students are estimated based on the plan of teaching hours and historical data.

\subsubsection{Refine the Analysis of Budget Variances}

In order to evaluate actual performance based on budgets, universities should compare the price and quantity through budget variance analysis. Revenue - expenditure activities are the basis for universities to prepare budgets and control such activities. Currently, universities provide policies and regulations for internal expenditures. Therefore, differences in costs should be controlled and analyzed carefully and reported to managers to find solutions. Decisions regarding tuition for each class and each program are important and difficult since they affect the number of students enrolling in a university and revenue of that university. If revenue cannot cover the costs incurred, it is difficult for the universities to survive even if they have effective cost control system. The determination of the tuition fee per student is based on the direct cost per student and other costs based on the university plan. To increase revenue, the university should utilize the full capacity of classrooms and available equipment to provide short-term night classes. These classes should only charge the direct costs to increase the participation of departments in universities and encourage students improve their knowledge and career skills after graduation. When analyzing budget variances, it is important to determine the causes of the increases in costs compared to the standard costs, thereby finding solutions and action plans for better cost control. The methods should be used are variance analysis and determining the changes due to price or quantity, identify objective and subjective causes to find suitable solutions.

\section{References}

Alau, S. (2009). An assessment of influence of budget process on budget performance. A Case study of Kwara State, Nigeria. Almasi, H., Palizdar, M. R., \& Parsian, H. (20I5). Budgetary participation and managerial performance: The impact of information and environmental volatility. Management Science Letters, 5, 843-854.

Ambetsa, W. O. A. (2004). Survey of the Budgeting Practices by Commercial Airlines Operating At Wilson Airport. University of Nairobi.

Anthony, R. N., \& Govindarajan, V. (200I). Management Control Systems (Vol. Twelfth Edition). Mc Graw Hill.

Blumentritt, T. (2006). Integrating strategic management and budgeting. Journal of business strategy, 27(6), 73-79.

Cropper, P., \& Cook, R. (2000). Developments: Activity-Based Costing in Universities-Five Years. . . Public Money \& Management, 20(2), 6I-68.

Drake, P. P., \& Fabozzi, F. J. (2010). The Basics of Finance: An Introduction to Financial Markets, Business Finance, and Portfolio Management (Vol. I92). John Wiley \& Sons.

Fisher, J. G., Maines, L. A., Peffer, S. A., \& Sprinkle, G. B. (2002). Using budgets for performance evaluation: Effects of resource allocation and horizontal information asymmetry on budget proposals, budget slack, and performance. The Accounting Review, 77(4), 847-865.

Frederick, D. (200I). Budgetary control. credit management, ABI/INFORM Global, 36-37.

Gacheru, N. (2012). The effect of budgeting process on Budget Variance in NGOs in Kenya. Unpublished MBA Project. University of Nairobi.

Gachithi, E. W. (2010). The Challenges of budget implementation in Public Institutions: A case study of University of Nairobi (Doctoral dissertation).

Hansen, D. R., \& Maryanne, M. Mowen. (2005). Cost Management Acounting Control. McGraw-Hill companies, Inc.

Horne, J., \& Hu, B. (2008). Mathematics and Computers in Simulation Estimation of cost efficiency of Australian universities. Mathematics and Computers in Simulation, 78(2-3), 266-275.

John, A., \& Ngoasong, L. (2008). Budgetary and management control process in a manufacturing: case of Guinness Nigerian plc. Unpublished Masters' Thesis, Mälardalen. Mälardalen University School of Sustainable Development of Society and Technology. 
Kamau, J. K., Rotich, G., \& Anyango, W. (2017). Effect of budgeting process on budget performance of state corporations in Kenya: A case of Kenyatta National Hospital. International Academic Journal of Human Resource and Business Administration, 2(3), 255-28I.

Kavoi, D. M. (201I). Factors that influence the achievement of budget targets: A case of the University of Nairobi. Unpublished MBA Project. University of Nairobi.

Little, H. T., Magner, N. R., \& Welker, R. B. (2002). The fairness of formal budgetary procedures and their enactment: Relationships with managers' behavior. Group \& Organization Management, 27(2), 209-225.

Lucey, T. (2002). Costing (6th edition). A survey of operational budgeting challenges the insurance industry in Kenya. University of Nairobi.

Muleri, M. A. (200I). A survey of budgeting practices among the major British Nongovernmental developments organizations in Kenya. An unpublished MBA dissertation, university of Nairobi.

Muthinji, E. M. (2009). Challenges of budget implementation in public sector organizations, a Case study of the Commissioner of Higher Education in Kenya. unpublished MBA Thesis, University of Nairobi, School of business.

Nguyen, M. T., \& Nguyen, H. V. (2015). Textbook of Survey Methods: Principles and practice. Hanoi: National Economics University Publishing House.

Qi, Y. (2010). The Impact of the Budgeting Process on Performance in Small and Medium-sized Firms in China.

Schick, A. (1998). A contemporary approach to public expenditure management. World Bank Institute, 68, 2-I I I.

Silva, L. M. D., \& Jayamaha, A. (2012). Budgetary process and organizational performance of apparel industry in Sri Lanka. Journal of emerging trends in economics and management sciences, 3(4), 354-360.

Suberu, S. B. (2010). Budgeting strategies in selected federal polytechnic libraries in Nigeria. Samaru journal of information studies, IO(I-2), I7-22.

Sugioko, S. (2010). The Impact of budget participation on job performance of university executives: A study of APTIKMember Universities in Indonesia. Kasetsart Journal, 3I(2), 27I-279.

Tavakkoli, M., \& Etemadi, H. (2007). The relationship between participation in budgeting and performance of managers and the effect of job-related information in the main companies affiliated with the Ministry of Petroleum. Daneshvar Scientific Research Bimonthly, I6 -23.

Weetman, P. (2006). Financial and management accounting, an introduction. Edinburgh: FT Prentice Hall.

Wong-On-Wing, B., Guo, L., \& Lui, G. (2010). Intrinsic and extrinsic motivation and participation in budgeting: Antecedents and consequences. Behavioral Research in Accounting, 22(2), I33-I53.

Zimmerman, J. L. (2003). Accounting for decision making and control, (4th edition). New York: McGraw-Hill.

\section{Copyrights}

Copyright for this article is retained by the author(s), with first publication rights granted to the journal. This is an open-access article distributed under the terms and conditions of the Creative Commons Attribution license (http://creativecommons.org/licenses/by/4.0/). 